\title{
Biomass burning in eastern Europe during spring 2006 caused high deposition of ammonium in northern Fennoscandia
}

Karlsson, Per Erik; Ferm, Martin; Pihl Karlsson, Gunilla; Hellsten, Sofie; Tømmervik, Hans; Hole, Lars R.; Akselsson, Cecilia; Ruoho-Airola, Tuija; Aas, Wenche; Mikkelsen, Teis Nørgaard

Total number of authors:

11

Published in:

Environmental Pollution

Link to article, DOI:

10.1016/j.envpol.2012.12.006

Publication date:

2013

Document Version

Publisher's PDF, also known as Version of record

Link back to DTU Orbit

Citation (APA):

Karlsson, P. E., Ferm, M., Pihl Karlsson, G., Hellsten, S., Tømmervik, H., Hole, L. R., Akselsson, C., RuohoAirola, T., Aas, W., Mikkelsen, T. N., \& Nihlgard, B. (2013). Biomass burning in eastern Europe during spring 2006 caused high deposition of ammonium in northern Fennoscandia. Environmental Pollution, 176, 71-79. https://doi.org/10.1016/j.envpol.2012.12.006

\section{General rights}

Copyright and moral rights for the publications made accessible in the public portal are retained by the authors and/or other copyright owners and it is a condition of accessing publications that users recognise and abide by the legal requirements associated with these rights.

- Users may download and print one copy of any publication from the public portal for the purpose of private study or research.

- You may not further distribute the material or use it for any profit-making activity or commercial gain

- You may freely distribute the URL identifying the publication in the public portal 


\title{
Biomass burning in eastern Europe during spring 2006 caused high deposition of ammonium in northern Fennoscandia
}

\author{
Per Erik Karlsson ${ }^{\mathrm{a}, *}$, Martin Ferm ${ }^{\mathrm{a}}$, Hans Tømmervik ${ }^{\mathrm{b}}$, Lars R. Hole ${ }^{\mathrm{c}}$, Gunilla Pihl Karlsson ${ }^{\mathrm{a}}$, \\ Tuija Ruoho-Airola ${ }^{\mathrm{e}}$, Wenche Aas ${ }^{\mathrm{f}}$, Sofie Hellsten ${ }^{\mathrm{a}}$, Cecilia Akselsson ${ }^{\mathrm{d}}$, Teis Nørgaard Mikkelsen ${ }^{\mathrm{g}}$, \\ Bengt Nihlgård ${ }^{\mathrm{h}}$ \\ a IVL Swedish Environmental Research Institute, Box 53021, SE-400 14 Gothenburg, Sweden \\ ${ }^{\mathrm{b}}$ The Norwegian Institute for Nature Research (NINA), Framsenteret, 9296 Tromsø, Norway \\ ${ }^{\mathrm{c}}$ The Norwegian Meteorological Institute, Allégaten 70, 5007 Bergen, Norway \\ d Department of Earth and Ecosystem Sciences, Lund University, Sölvegatan 12, SE-223 62 Lund, Sweden \\ e Finnish Meteorological Institute, P.O. Box 503, FI-00101 Helsinki, Finland \\ ${ }^{\mathrm{f}}$ Norwegian Institute for Air Research (NILU), P.O. Box 100, 2027 Kjeller, Norway \\ ${ }^{\mathrm{g}}$ Department of Chemical and Biochemical engineering, Technical University of Denmark, Frederiksborgvej 399, 4000 Roskilde, Denmark \\ ${ }^{\mathrm{h}}$ Department of Biology, Lund University, Sölvegatan 37, SE-223 62 Lund, Sweden
}

\section{A R T I C L E I N F O}

\section{Article history:}

Received 4 July 2012

Received in revised form

12 December 2012

Accepted 14 December 2012

\section{Keywords:}

Ammonium deposition

Biomass burning

Vegetation damage

Northern latitudes

Eastern Europe

\begin{abstract}
A B S T R A C T
High air concentrations of ammonium were detected at low and high altitude sites in Sweden, Finland and Norway during the spring 2006, coinciding with polluted air from biomass burning in eastern Europe passing over central and northern Fennoscandia. Unusually high values for throughfall deposition of ammonium were detected at one low altitude site and several high altitude sites in north Sweden. The occurrence of the high ammonium in throughfall differed between the summer months 2006, most likely related to the timing of precipitation events. The ammonia dry deposition may have contributed to unusual visible injuries on the tree vegetation in northern Fennoscandia that occurred during 2006, in combination with high ozone concentrations. It is concluded that long-range transport of ammonium from large-scale biomass burning may contribute substantially to the nitrogen load at northern latitudes.
\end{abstract}

(c) 2013 Elsevier Ltd. All rights reserved.

\section{Introduction}

Nitrogen deposition may increase in high latitude regions due to climate change (Hole and Enghardt, 2008) as well as due to increased shipping activities in the Arctic (Corbett et al., 2010). Furthermore, the Arctic and sub-Artic ecosystems are experiencing considerable changes in the climate, both during summer and winter (Bokhorst et al., 2009; Karlsen et al., 2009). Nitrogen deposition has been shown to influence forest, heathland and bog ecosystems even on remote parts of Europe (Bobbink and Hettelingh, 2011; Dise et al., 2001; Phoenix et al., 2012). Northern ecosystems are especially vulnerable to nitrogen deposition, as bryophytes and lichens are important parts of these ecosystems and as bryophytes and lichens take the major part of their nutrition directly from the air (Cornelissen et al., 2001; Gordon et al.,

\footnotetext{
* Corresponding author.

E-mail address: pererik.karlsson@ivl.se (P.E. Karlsson).
}

2001; Bates, 2002). Furthermore, nitrogen may increase primary productivity of the ecosystems and above a certain level it is common that a few competitive species are able to exploit the available $\mathrm{N}$ and to dominate other species by shading and lead to changed biodiversity (Dise et al., 2001; Stevens et al., 2011; Phoenix et al., 2012). An effect threshold for annual nitrogen deposition to arctic and alpine ecosystems has been suggested to between 5 and $15 \mathrm{~kg} \mathrm{~N} / \mathrm{ha}$ (Bobbink et al., 2010; Bobbink and Hettelingh, 2011).

There has been an increase in $\mathrm{NO}_{x}$ and $\mathrm{NH}_{y}$ deposition at northern latitudes since 1860 (Galloway et al., 2004; Hole et al., 2009; Vestreng et al., 2009; Ruoho-Airola et al., 2012) as a result of industrialization and intensified farming. After the 1990s there has been a decline in the observed concentrations of nitrogen components in air and precipitation over Europe as a result of emission reduction measures such as the UN-ECE Gothenborg protocol (Tørseth et al., 2012). Future increased precipitation may however again increase deposition of sulphur and nitrogen compounds in northern regions (Hole and Enghardt, 2008). The current 
deposition of $\mathrm{NO}_{x}$ and $\mathrm{NH}_{y}$ in northern Norway and northern Sweden has been estimated to below $2 \mathrm{~kg} \mathrm{~N} / \mathrm{ha}$ (Aas et al., 2008; Pihl Karlsson et al., 2011).

The alkaline $\mathrm{NH}_{3}$ reacts readily with acidic substances in the atmosphere to form ammonium salt particles, such as $\left(\mathrm{NH}_{4}\right)_{2} \mathrm{SO}_{4}$, $\mathrm{NH}_{4} \mathrm{NO}_{3}$ and $\mathrm{NH}_{4} \mathrm{Cl}$, that occur predominantly in the fine particle fraction (Hertel et al., 2011). $\left(\mathrm{NH}_{4}\right)_{2} \mathrm{SO}_{4}$ can under certain meteorological conditions be transported over long distances (Brosset et al., 1975; Irwin and Williams, 1988; Krupa, 2003). In the absence of sulphate, $\mathrm{NH}_{3}$ will mainly react with $\mathrm{HNO}_{3}$ and form $\mathrm{NH}_{4} \mathrm{NO}_{3} . \mathrm{NO}_{3}$ containing particles in general have higher deposition velocities as compared to $\mathrm{SO}_{4}$ containing particles (Erisman et al., 1997).

Emissions from the large-scale biomass burning represent an important component of the hemispheric air pollution (Yurganov et al., 2004; Simmonds et al., 2005). There are however not many studies of linking pollution of reduced nitrogen with biomass burning. Agricultural activities, including livestock productivities and fertilizing, are by far the most important source of ammonia, but biomass burning may also be a significant source (Krupa, 2003; Lamarque et al., 2010; Hecobian et al., 2011). During the last decade there have been several large-scale biomass burning events in eastern Europe. Over the past decade, improved remote sensing has permitted a more accurate assessment of the annual fires in Russian boreal forest, revealing that Russia in general has the largest area burned among boreal forests (Goldammer, 2010). Comparative fire statistics for total vegetated area and forest area burned in the Russian Federation in the period 2000-2007 are presented in Fig. 1, based on agency reports and remote sensing. The number of forest fires in Russia has increased from an annual average of 17800 fires during the period 1986-1990 to 21700,30000 and 29300 fires for during the periods 1991-1995, 1996-2000 and 2001-2005, respectively (Goldammer, 2010) For the year 2006, Goldammer (2010) reports 36 000, 1306 and 3800 fires in Russia, Belarus and Ukraine, respectively. Increased fire activity due to climate change is anticipated in the circumboreal forest (Flannigan et al., 2009). There are large inter annual variability of the magnitude and importance of biomass burning (van der Werf et al., 2006), for Russia this is illustrated in Fig. 1 where 2003 and 2006 seem to be important years.

Transport of air pollution from biomass burning depends on the weather situation during the period of burning as well as the plume height of the fire, i.e. the amount of heat in the system. In the beginning of May 2006, there was an unusual episode with snow at Svalbard coloured black (Stohl et al., 2007). There were also record high concentrations of ozone and most other pollutants detected on Svalbard, as well as on Iceland. This highly polluted air originated from biomass burning in eastern Europe and it

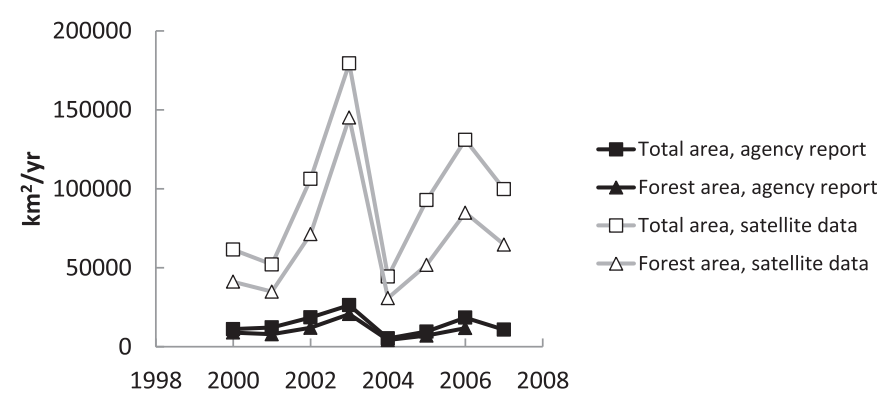

Fig. 1. Comparative fire statistics for total vegetated area and forest area burned in the Russian Federation during the period 2000-2007, based on agency reports and remote sensing. Source: Goldammer, 2010. was estimated that approximately $2 \mathrm{M}$ ha burnt during May and June 2006 (Stohl et al., 2007). An anti-cyclonic weather system over Russia transported this polluted air towards west and north, ending up from Scotland to Finland (Anttila et al., 2008; Whitham and Manning, 2007). Significant concentrations of several pollutants, among them ammonium, were detected in the polluted snow on Svalbard (Stohl et al., 2007). High amounts of ammonium were also detected in the PM10 particles sampled in Virolahti, southeastern Finland close to the border of Russia, during May 2006 (Anttila et al., 2008).

Trajectory analysis (Fig. 2) showed that some of these distinct, polluted air masses were transported across central and northern Fennoscandia, in particular the county of Jämtland in central Sweden. In connection with these pollution episodes during 2006, some unusual vegetation damage was detected in northern Fennoscandia (Manninen et al., 2009).

The aims of this study were to analyse occurrence of high amounts of ammonia/ammonium in the air and deposition at northern latitudes in Fennoscandia, to examine links to large scale biomass burning events and to analyse the possible role for the occurrence of visible damage on the vegetation.

\section{Methods}

2.1. Sites

In this study, results were used from sites within different monitoring networks in Finland, Sweden and Norway (Fig. 3). Air concentration values were used from the EMEP (European Monitoring and Evaluation Program, www.emep.int) sites Virolaht and Utö in Finland, Bredkälen and Esrange, in Sweden and Tustervatn in Norway. Trajectory analysis was also used for the Norwegian EMEP site Karasjok. In addition, air concentrations were measured at high altitudes in the Swedish mountain region in a special project. These sites were Katterjåkk, Tjärnberg, Skorvfjället and Prästbodarna. Data for throughfall- and bulk-deposition was used from several sites in Sweden operated by the Swedish Throughfall Monitoring Network (SWETHRO, Pihl Karlsson et al., 2011), both at low (Nymyran, Sör-Digertjärn, Storulvsjön) and high (Branten, Sånfjället, Hundshögen, Fiskåfjället) altitudes. Information on bulk- and throughfall-deposition data was also used from the Norwegian EMEP site Tustervatn.

\subsection{Air concentration sampling and analysis}

The air concentration samples were measured at all sites in Finland, Sweden and Norway according to the EMEP Manual (EMEP, 1996). Measurements in Finland have been described in detail by Karlsson et al. (2007). At the high altitude sites in Sweden, sampling was made with the same air flow rate as the EMEP sites (15 l/min) intermittently $5 \mathrm{~min}$ every $30 \mathrm{~min}$. The amount of black smoke collected on the firs filter at the Swedish site Bredkälen was determined using an optical, reflectance method (ISO 9835:1993). The authors recognize that "black smoke" is a poorly defined group of substances and that there are large uncertainties in the quantification. However, in this article the data are mainly used as a tracer for large air pollution episodes.

\subsection{Deposition sampling and analysis}

Samples from the bulk- and throughfall-deposition measurements within the SWETHRO network in Sweden were collected and analysed as described by Pihl Karlsson et al. (2011). The throughfall measurements at Swedish high altitude sites Katterjåkk (515 m a.s.l), Tjärnberg (500 m a.s.l.), Skorvfjället (808 $\mathrm{m}$ a.s.l) and Prästbodarna (680 m a.s.l), were similar to those described above for the SWETHRO network, with some differences. The density of trees is low at the elevational tree line. A random positioning of throughfall collectors would therefore mainly result in precipitation collection. Therefore the five throughfall collectors were positioned directly under single Norway spruce trees. Even though the absolute values for throughfall might be somewhat uncertain due to this arrangement, the relative values between years should be reliable.

\subsection{Meteorological information}

Meteorological information for the different sampling sites in Sweden was provided by the weather service ("LuftWeb") provided by the Swedish Meteorological and Hydrological Institute (SMHI). Estimates can be obtained for each position in Sweden based on interpolated weather data. 
A

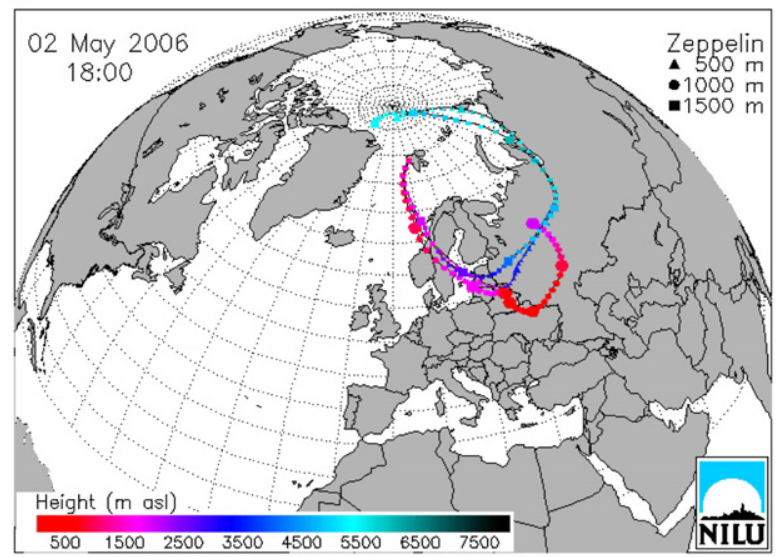

$\mathrm{B}$

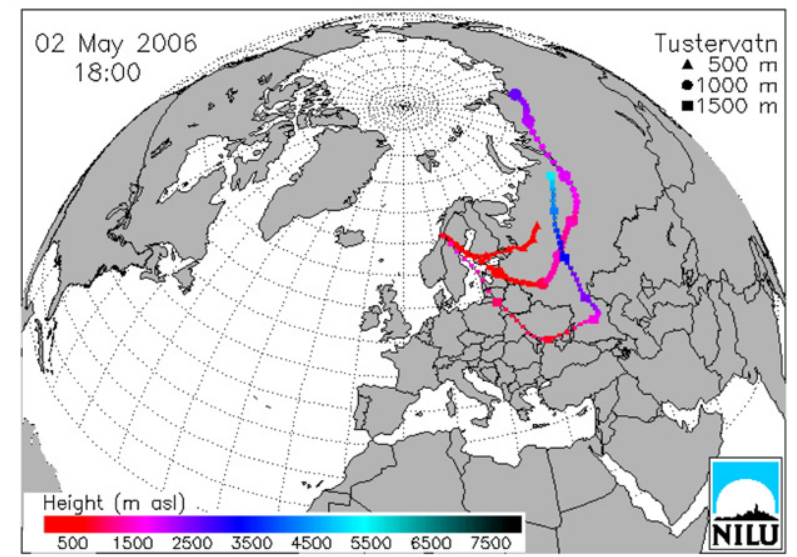

C

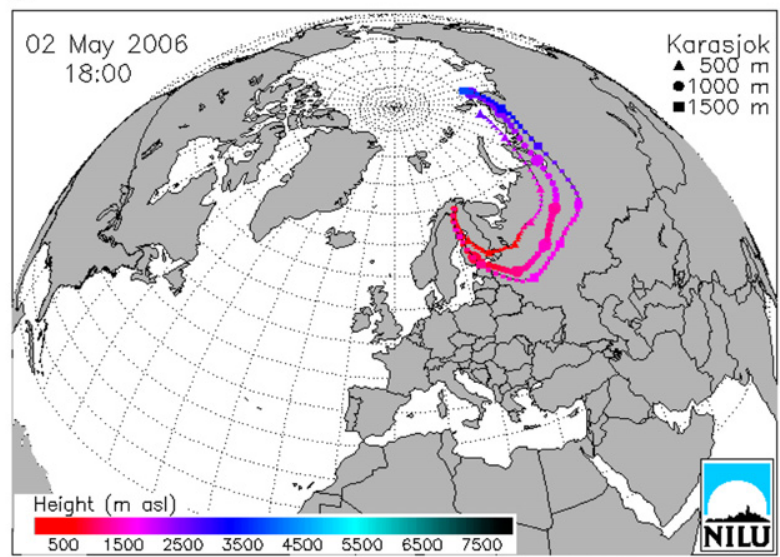

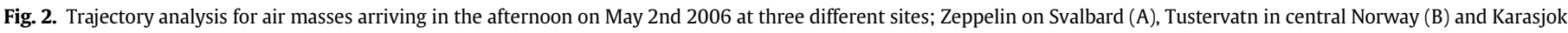

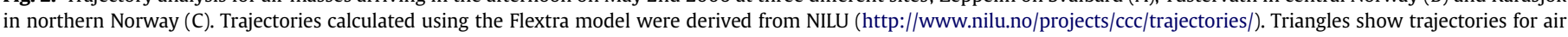

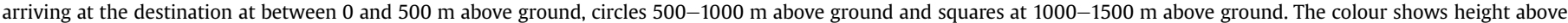
ground during air mass transport. (For interpretation of the references to colour in this figure legend, the reader is referred to the web version of this article.)

\section{Results and discussion}

\subsection{Air concentrations of pollutants over Finland, Sweden and Norway}

Concentrations of black smoke can be used as an indicator for polluted air originating from biomass burning (Hyvärinen et al., 2011). Daily mean air concentrations of black smoke during 2006 are shown in Fig. 4 for the EMEP monitoring site Bredkälen, positioned in the county of Jämtland, Sweden. There was a clear event around the beginning of May, where the concentrations of black smoke started to rise above the baseline level around April 26 and maximum daily mean concentration, $12 \mu \mathrm{g} / \mathrm{m}^{3}$, was measured on May 2. The concentrations returned to baseline levels around May 13.

The daily mean air concentrations of $\mathrm{NH}_{3}+\mathrm{NH}_{4}^{+}$ (gaseous + particle, hereafter referred to as total $\mathrm{NH}_{x}$, however for Tustervatn only particle concentrations of $\mathrm{NH}_{4}^{+}$were included, since there is a well-documented problem with local emissions of $\mathrm{NH}_{3}$ at this site) and $\mathrm{SO}_{4}^{2-}$ during 2006 are shown in Fig. 5 for Utö, Bredkälen and Tustervatn. All three sites are positioned so that the polluted air masses from eastern Europe during the beginning of May (Fig. 2) passed over. High air concentrations of $\mathrm{NH}_{x}$ and $\mathrm{SO}_{4}^{2-}$ were detected at all three sites during the period 25 April-13 May 2006. However, there were high concentrations measured also during other parts of 2006. At Utö, the highest daily air concentration of total $\mathrm{NH}_{x}$ for the year 2006 was measured on May 3rd. The high concentrations of total $\mathrm{NH}_{x}$ at Utö were accompanied by relatively high concentrations of $\mathrm{SO}_{4}^{2-}$. Also at Bredkälen, the highest daily air concentration of total $\mathrm{NH}_{x}$ for the year 2006 was measured on May 3rd, and also here this was accompanied by high concentrations of $\mathrm{SO}_{4}^{2-}$. Finally, at Tustervatn there was a distinct episode for particulate $\mathrm{NH}_{4}^{+}$and $\mathrm{SO}_{4}^{2-}$, as well as for other pollutants measured at the site in the period from end of April to 10 May 2006, with the highest peak at 2nd May. The ozone concentrations during this period were among the highest ever observed at Tustervatn. What makes the episode special was the record high concentration of potassium, $0.27 \mu \mathrm{g} / \mathrm{m}^{3}$, measured during this period (data not shown), which confirms that the source of air pollution was from biomass burning (Chaiyo et al., 2011).

At the high altitude sites in northern Sweden, air concentrations of pollutants were measured on a monthly basis (Fig. 6). Even though the air concentrations for May 2006 were not always record high, there were high values also in particular during 2003, the values for May 2006 were always among the highest during the period of measurements. Also high sulphur, potassium and calcium concentrations were detected. The concentrations of calcium were record high at all sites during May 2006. High concentrations of calcium are also a typical component of particulate emissions from forest fires (Chaiyo et al., 2011). 


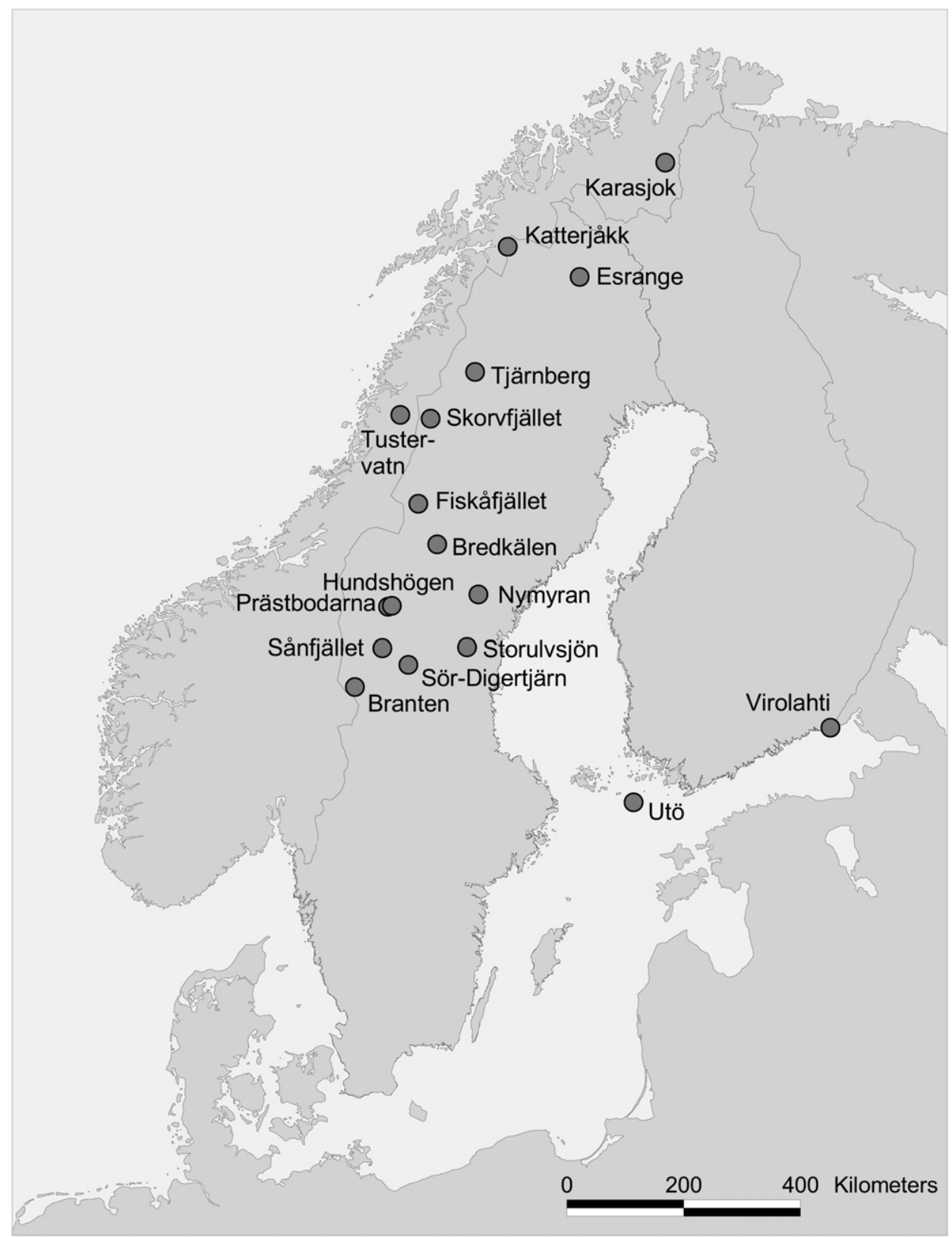

Fig. 3. Map showing the positions of the different monitoring sites.

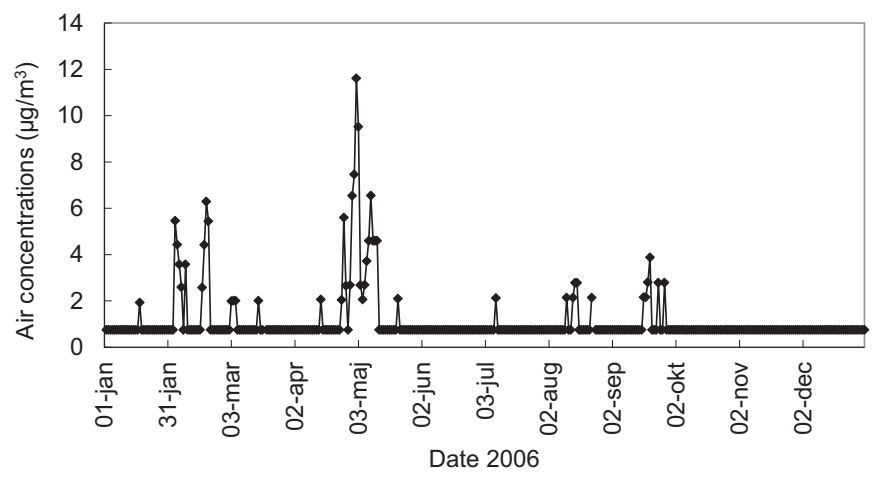

Fig. 4. Daily mean air concentrations of black smoke during 2006 for the EMEP monitoring site Bredkälen, positioned in the middle of the county of Jämtland, Sweden.
During the period April-May 2006, there were also unusually high ozone concentrations detected at the monitoring sites Tustervatn and Esrange (Fig. 7). There were several episode days with hourly ozone concentrations ranging 75-81 ppb between April 26th, and May 10th. There was, however, also one more ozone episode at these sites later during 2006, with ozone concentrations at Tustervatn on June 12 th up to $87 \mathrm{ppb}$. There were also high ozone concentrations on July 7 th. The ozone concentrations were not so high at Bredkälen during these periods, with a maximum of $55 \mathrm{ppb}$ (data not shown). Thus, the polluted air masses passing over northern Fennoscandia in the spring and summer of 2006 also contained volatile organic compounds and nitrogen oxides leading to a high ozone formation under the prevailing sunny weather conditions during this time.

Overall, the results may be interpreted as that there were several events with polluted air masses passing over central and 
A

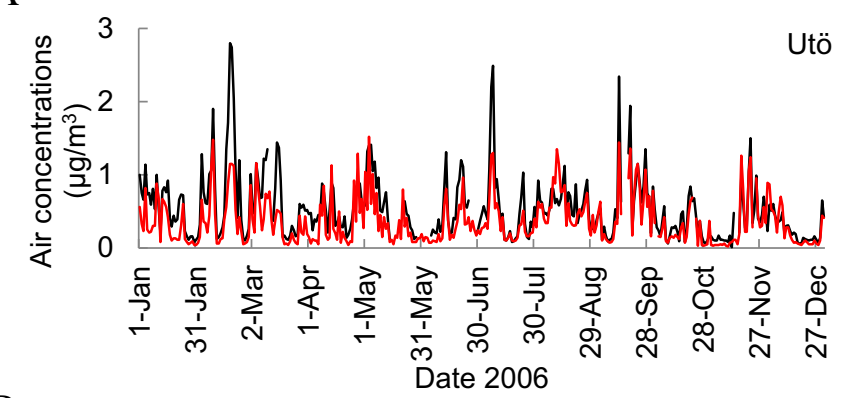

B

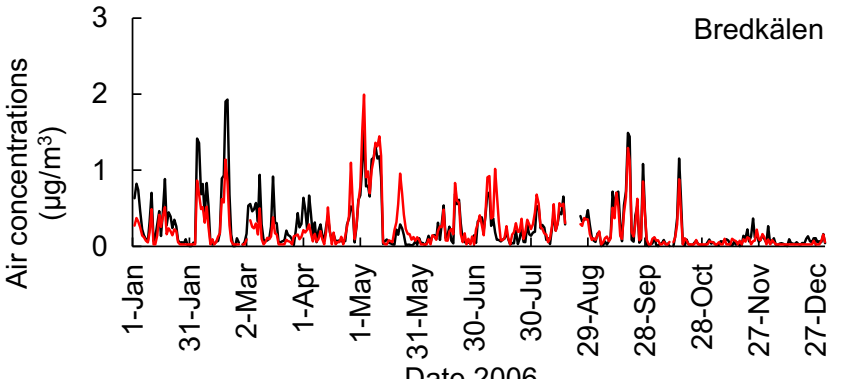

$\mathrm{C}$

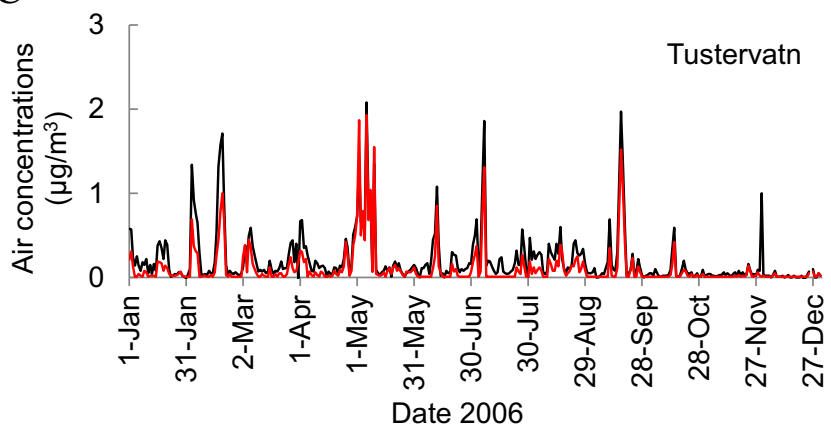

$-\mathrm{NH} 4-\mathrm{N}$

-SO4-S

Fig. 5. Daily mean air concentrations of $\mathrm{NH}_{3}+\mathrm{NH}_{4}^{+}$(gaseous + particles, at Tustervatn only particles) and $\mathrm{SO}_{4}^{2-}$ during 2006 at three different sites, Utö in Finland (A), Bredkälen in Sweden (B) and Tustervatn in Norway (C).

northern Fennoscandia at high altitudes during the spring and summer 2006, moving in slightly different directions. One welldocumented event in particular, during the end of April and beginning of May, resulted in high air concentrations of $\mathrm{NH}_{3} / \mathrm{NH}_{4}^{+}$ detected also at low altitude monitoring sites along the trajectory pathway. That the polluted air masses in May originated from biomass burning in eastern Europe was confirmed by trajectory analysis (Fig. 2), but also by measurements of air concentrations of levoglucosan at Helsinki and Svalbard (Stohl et al., 2007; Saarikoski et al., 2008). However, the air plume was transported over other source areas and it is possible that some of the enhanced reduced nitrogen also originated from other sources that the plume took up on its way.

\subsection{Deposition}

An unusually high monthly value for ammonium deposition in throughfall was detected at Nymyran in June 2006, a site with a 75year-old Norway spruce forest at an altitude of $300 \mathrm{~m}$ a.s.l in the county of Jämtland, Sweden (Fig. 8). The sample volume was relatively normal but the $\mathrm{NH}_{4}^{+}$concentration in the sample was high. The sample was carefully checked for contamination, but there was no sign of bird droppings such as e.g. high pH or high phosphorous concentrations. Analysis of Kjeldahl-N showed that the sample content of organic $\mathrm{N}$ was relatively low.

Throughfall measurements at two nearby Swedish sites, SörDigertjärn under Scots pine and Storulvsjön under Norway spruce, and at the nearby Norwegian site Tustervatn under Norway spruce (Fig. 3), did not show elevated $\mathrm{NH}_{4}^{+}$or Kjeldahl-N deposition during 2006 (data not shown).

The sampling of throughfall deposition is, of course, heavily dependent on precipitation amounts. Therefore we did a careful analysis of the daily precipitation events at the site Nymyran (Fig. 9). The analysis was based on interpolated data on daily precipitation for the exact position of the Nymyran site, provided by the Swedish Meteorological and Hydrological Institute (SMHI). There were only small amounts of precipitation during the period between the pollution event on 2-3 May 2006 and the end of the May sampling period for throughfall at Nymyran (Fig. 9). Between May 1st and the turn of the sampling period on May 22nd 2006, the accumulated precipitation was only $15 \mathrm{~mm}$ and the daily maximum precipitation $5 \mathrm{~mm}$. In contrast, during the nine days between $22 \mathrm{nd}$ May and 31st May 2006, the accumulated precipitation was $49 \mathrm{~mm}$. Hence, this analysis shows that the high amounts of $\mathrm{NH}_{4}^{+}$found in the June 2006 throughfall sample from Nymyran might well have included dry deposition from the highly polluted air masses that passed over the county of Jämtland in the beginning of May 2006. There was little precipitation during the remaining part of the May sampling period but substantial precipitation to wash out the $\mathrm{NH}_{4}^{+}$ to the throughfall samplers during the June sampling period.

Monthly ammonium deposition in throughfall is shown in Fig. 10 for three sites at high altitude $(600-800 \mathrm{~m}$ a.s.l) in the county of Jämtland. All three sites show high monthly ammonia deposition during summer 2006, but at different months, also as compared to Nymyran. The relative ammonia deposition peak value for Hundshögen was not as high compared to the other sites. No Kjeldahl-nitrogen analyses are available for these sites. Elevated $\mathrm{NH}_{4}^{+}$deposition in throughfall at high altitudes was also evident at four other sites outside the county of Jämtland (data not shown), one site south of Jämtland (Branten) and three sites at different distances north of Jämtland (Skorvfjället, Tjärnberg and Katterjåkk, Fig. 3). At these sites the $\mathrm{NH}_{4}^{+}$peak during 2006 occurred in June or July. However, the peaks at these sites were not as pronounced during 2006, as compared to peaks during other years. Similar to what was described for Nymyran, the appearance of $\mathrm{NH}_{4}^{+}$in the throughfall samples at different months at different sites most likely depended on the precipitation pattern at the respective site (data not shown).

There were no measurements of bulk deposition at the site Nymyran during 2006. However, there were bulk deposition measurements available from the nearby site Storulvsjön (Fig. 3). There were no pronounced peaks in the monthly, bulk $\mathrm{NH}_{4}^{+}$deposition during 2006 at Storulvsjön (data not shown).

To summarize, several monthly pronounced $\mathrm{NH}_{4}^{+}$throughfall deposition events were detected during the summer of 2006, both at low and high altitudes, in particular in the county of Jämtland, but also in other parts of northern Sweden. These events occurred during different months, probably related to the timing of precipitation events. It is likely that the deposition to the forests occurred as dry deposition and then was washed to the throughfall sampling collectors when there was enough precipitation. The dry deposition at Nymyran most likely occurred during the pollution episode in the beginning of May 2006, originating from biomass burning in eastern Europe, but for the other sites the deposition might be related to other pollution episodes during the summer 2006.

It is difficult to quantify the $\mathrm{NH}_{4}^{+}$deposition to the forests in northern Sweden, since a large fraction of the nitrogen deposition 
A

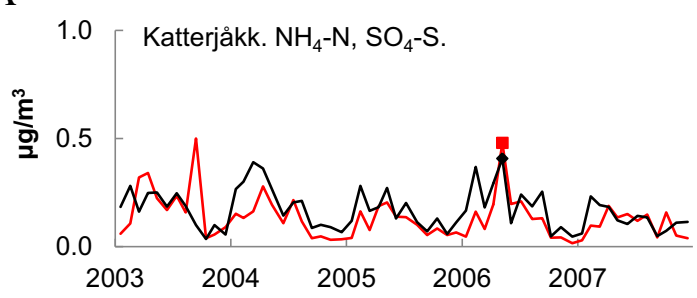

B

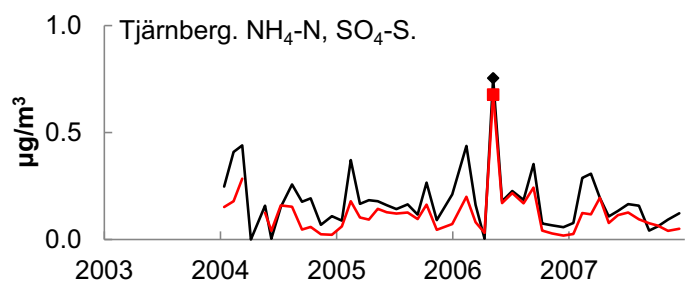

C

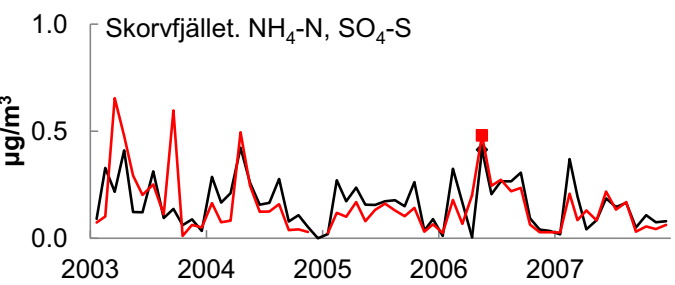

$\mathrm{D}$

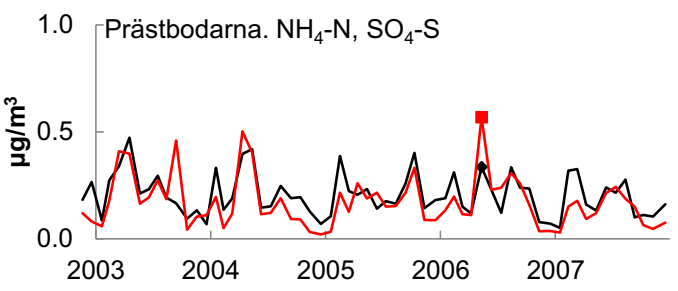

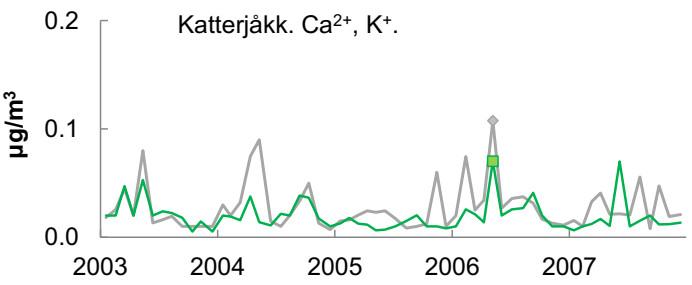
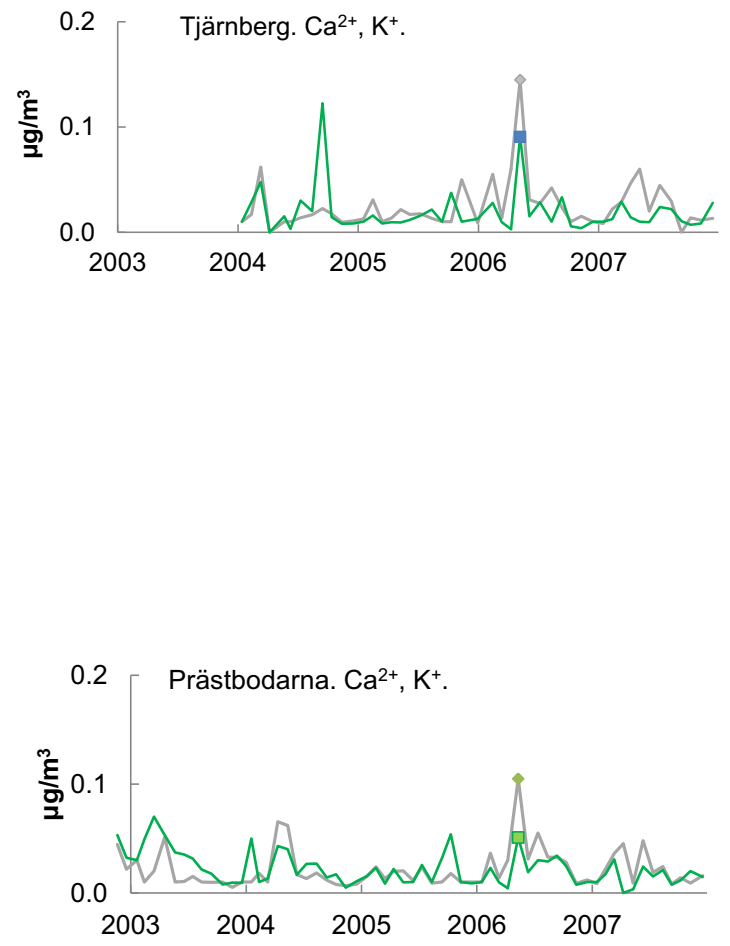

$-\mathrm{NH} 4-\mathrm{N}$

- SO4-S

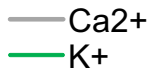

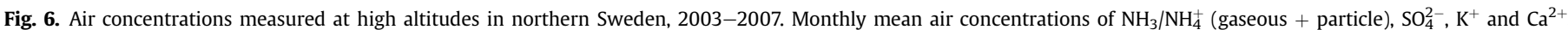

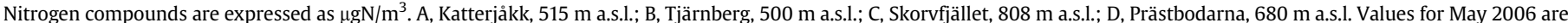
indicated with a symbol. Air concentrations of $\mathrm{Ca}^{2+}$ and $\mathrm{K}^{+}$were not available for Skorvfjället.

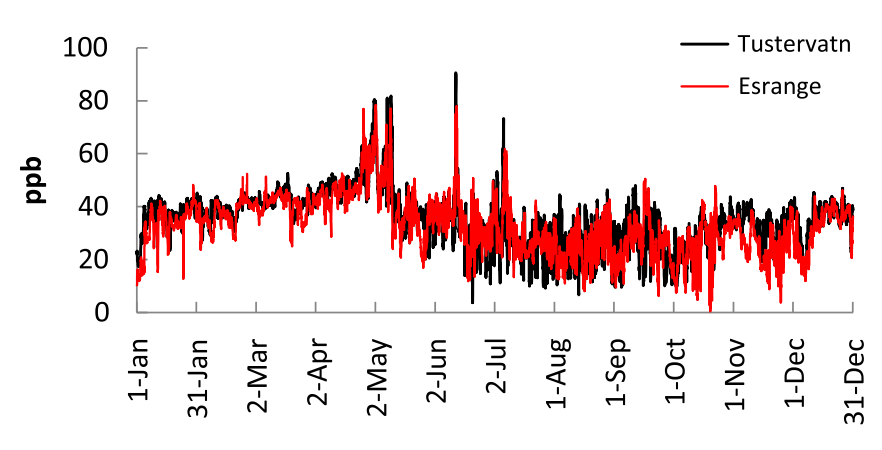

Date 2006

Fig. 7. Hourly ozone concentrations measured during 2006 at the Swedish sites Bredkälen and Esrange, the Finnish site Utö and the Norwegian site Tustervatn. generally is taken up directly to the canopies and not included in the throughfall measurements (Parker, 1983; Ferm, 1993; Adriaenssens et al., 2012). The fraction of nitrogen taken up directly to the canopy is particularly large in low deposition regions, such as northern Sweden. During five years, 1997-2001, there were parallel measurements of bulk- and throughfall-deposition measurements at Nymyran. On average, the annual throughfall deposition measured was only $20 \%$ of the annual bulk deposition (data not shown). Normally, the dry deposition of nitrogen compounds at these high latitudes is small, due to the long distance from major emission sources at continental Europe, so the total deposition to the forests and to the open field should in principle be similar (mediated by wet deposition). Hence, at normal low levels of deposition approximately $80 \%$ of the nitrogen deposition to the canopy at Nymyran would have been taken up directly by the canopy, not reaching the throughfall collectors. However, in this unusual case with high ammonium deposition, it can be assumed that the 
A

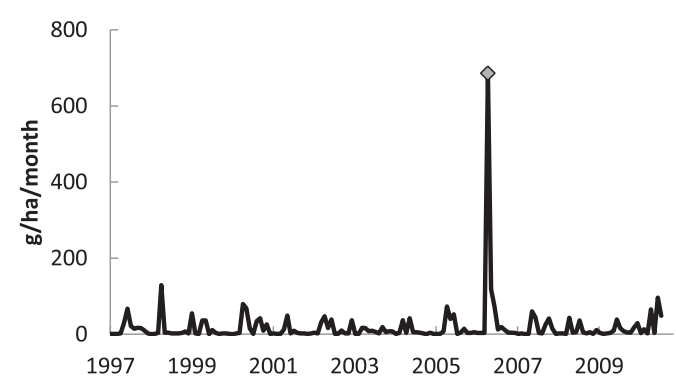

B

Nymyran, NH4-N concentrations

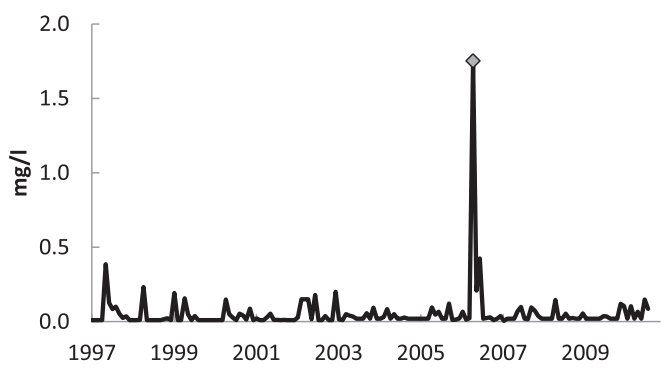

C

Nymyran, sample volume

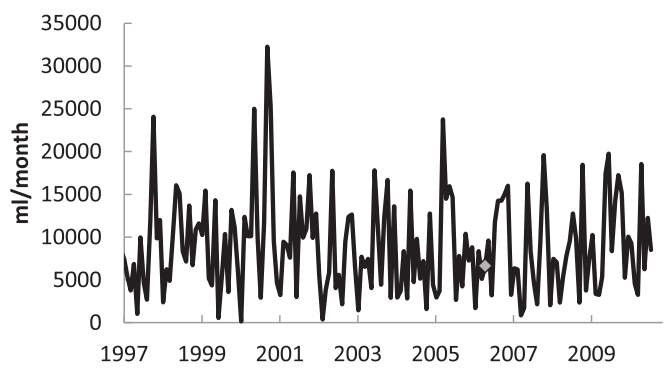

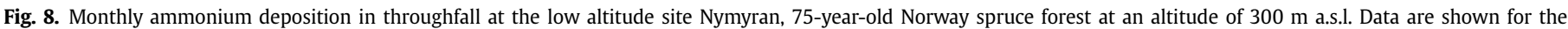
calculated deposition (upper), the sample ammonium concentration (middle) and the sample volume (lower). A symbol is used for the value for June 2006.

fraction taken up directly by the canopy would be less. In any case, it seems likely to assume that the deposition of total $\mathrm{NH}_{4}^{+}$at Nymyran during May and June 2006 at least exceeded $1 \mathrm{~kg} \mathrm{~N} / \mathrm{ha}$. Since the normal, annual deposition of inorganic $\mathrm{N}$ in north Sweden is below $2 \mathrm{~kg} \mathrm{~N} /$ ha (Pihl Karlsson et al., 2011), this $\mathrm{NH}_{4}^{+}$deposition
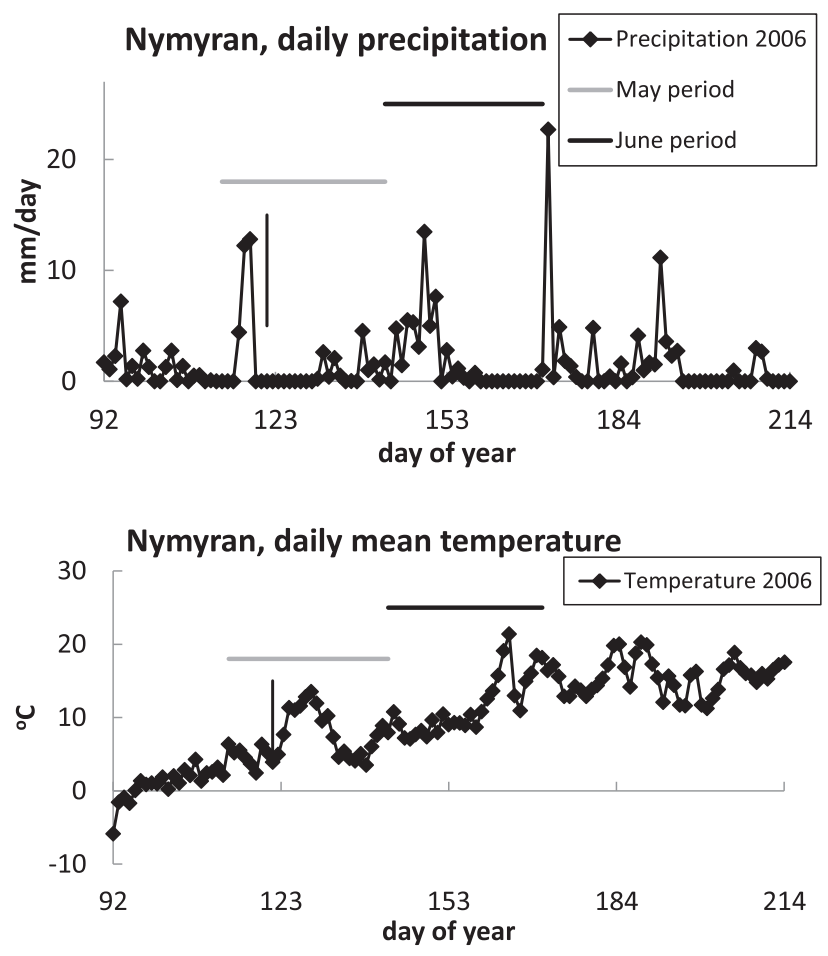

Fig. 9. Daily precipitation and daily mean temperatures at the site Nymyran for the period 1 April-31 July, 2006. The horizontal grey line indicates the sampling period for throughfall at Nymyran for May 2006 and the thick black horizontal bar the corresponding period June 2006. The thinner, vertical, black line indicates the date 1 May 2006. event is of considerable importance. It has been shown that nitrogen wet deposition at Svalbard is strongly depending on a few episodic "strong" events (Kühnel et al., 2011) and a similar conclusion was made also for sulphur deposition at remote sites in Finland (Ruoho-Airola and Salmi, 2001).

Ammonia is generally emitted in a highly water-soluble form (e.g. Ferm, 1998). It will consequently to a large extent be dry deposited close to the source. Alternatively ammonia can form salt particles with available sulphuric acid droplets and gaseous nitric acid shortly after being emitted. These particles are in a size range that has a relatively low deposition rate to the ground. They are mainly scavenged out by clouds and sooner or later deposited to the ground as precipitation. Hence, in order for long-range transport of $\mathrm{NH}_{x}$ to occur, there must be high concentration of acidic species available and cloud-free weather (Ferm and Hellsten, 2012). ERA interim reanalysis data from the European Centre for MediumRange Weather Forecasts (ecmwf.int) showed that a large anti cyclone was present above southeast Europe before and during the transport event in early May 2006. A very moderate large scale precipitation belt over Poland and the Baltic Sea (1-2 mm per day) was probably not enough to scavenge the particles generated from the fires during the rapid air mass transport towards northwest.

During the spring and summer 2006 unusual leaf visible injuries were observed on deciduous trees like birch (Betula pubescens) and rowan (Sorbus aucuparia) in northern Fennoscandia. Manninen et al. (2009) presumed these injuries to be effects of high $\mathrm{O}_{3}$ concentrations. Similar injuries to these species, like what was observed in 2006, have not been observed during other periods (Tömmervik, personal communication). It is possible that the combined exposure to high ammonium deposition may exacerbate the impacts of other components like $\mathrm{O}_{3}$ on vegetation, resulting in these unusual vegetation symptoms. Occasional frost nights during the spring of 2006 (annual reports: www.met.no; www.smhi.se) may also have reinforced the sensitivity and hence the injury (Manninen et al., 2009). Hence, there is a possibility that the dry deposition of ammonium might have contributed to these injuries, together with high $\mathrm{O}_{3}$ concentrations. 
A

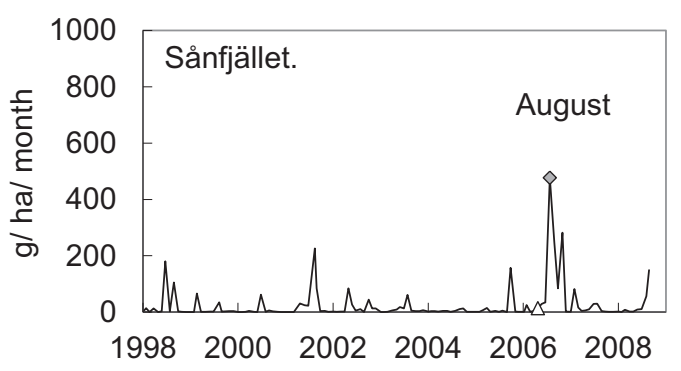

B

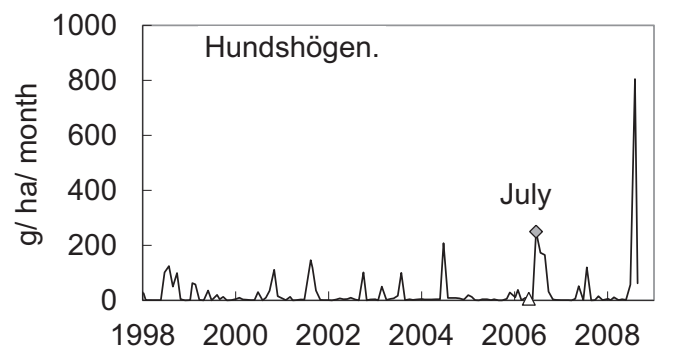

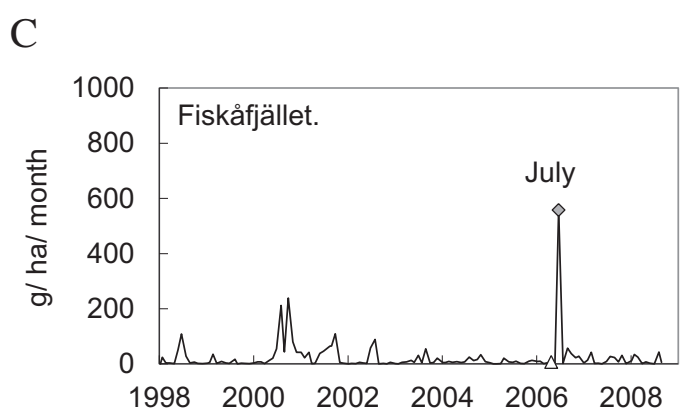

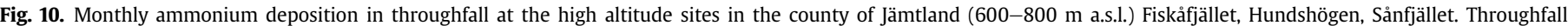

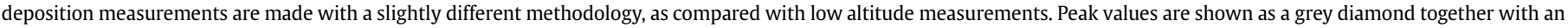
indication of the month. Values for May 2006 are shown as an open triangle.

\section{Conclusions}

Unusually high air concentrations of gaseous and particulate ammonia/ammonium were detected at high altitudes in central and northern Fennoscandia during May 2006, coinciding with a well described event with highly polluted air originating from large scale biomass burning in eastern Europe, passing over central Fennoscandia. High air concentrations of ammonia/ammonium and sulphate were also detected at low altitude areas over which this polluted air mass passed; at Utö, a small island between Finland and Sweden, at Bredkälen in the county of Jämtland, Sweden and at Tustervatn, a Norwegian site just north for Jämtland. At Tustervatn high potassium levels confirmed that the sources of air pollution was from biomass burning. At Bredkälen, also high air concentrations of black smoke were detected. Unusually high values for throughfall deposition of ammonium were detected during the summer 2006 at one low altitude site and several high altitude sites in the county of Jämtland. The occurrence of the high ammonia in throughfall in Jämtland varied between different summer months most likely related to precipitation events. The high ammonia air concentrations and dry deposition might have contributed to unusual visible injuries on the tree vegetation in northern Scandinavia occurred during 2006.

Long-range transport of polluted air from large scale biomass burning might have an important role for nitrogen deposition in northern Fennoscandia in a future climate change perspective.

\section{Acknowledgements}

The preparation of this article was financed by the Nordic Council of Minister (NMR). The deposition measurements in Sweden were operated by the Swedish Throughfall Monitoring Network (SWETHRO). The air pollution concentration and deposition measurements at high altitudes in the Swedish mountain region were financed by the Swedish Environmental Protection Agency. NILU is acknowledged for providing the FLEXTRA trajectories (www.nilu.no/trajectories) used in this study.

\section{References}

Adriaenssens, S., Hansen, K., Staelens, J., Wuyts, K., De Schrijver, A., Baeten, L., Boeckx, P., Samson, R., Verheyen, K., 2012. Throughfall deposition and canopy exchange processes along a vertical gradient within the canopy of beech (Fagus sylvatica L.) and Norway spruce (Picea abies (L.) Karst). Science of the Total Environment 420, 168-182.

Anttila, P., Makkonen, U., Hellén, H., Kyllönen, K., Leppänen, S., Saari, H., Hakola, H. 2008. Impact of the open biomass fires in spring and summer of 2006 on the chemical composition of background air in south-eastern Finland. Atmospheric Environment 42, 6472-6486.

Aas, W., Hjellbrekke, A.-G., Hole, L.R., Tørseth, K., 2008. Deposition of Major Inorganic Compounds in Norway 2002-2006. NILU OR 72/2008.

Bates, J.W., 2002. Effects on bryophytes and lichens. In: Bell, J.N.B., Treshow, M. (Eds.), Air Pollution and Plant Life, second ed. Wiley and Sons, Chichester, pp. 309-342.

Bobbink, R., Hicks, K., Galloway, J., Spranger, T., Alkemade, R., Ashmore, M. Bustamante, M., Cinderby, S., Davidson, E., Dentener, F., Emmett, B., Erisman, J.W., Fenn, M., Gilliam, F., Nordin, A., Pardo, L., De Vries, W., 2010. Global assessment of nitrogen deposition effects on terrestrial plant diversity: a synthesis. Ecological Applications 20, 30-59.

Bobbink, R., Hettelingh, J.-P. (Eds.), 2011. Review and Revision of Empirical Critical Loads and Dose-response Relationships. National Institute for Public Health and the Environment, Bilthoven, The Netherlands, ISBN 978-90-6960-251-6. Report 680359002.

Bokhorst, S.F., Bjerke, J.W., Tømmervik, H., Callaghan, T., Phoenix, G.K., 2009. Winter warming events damage sub-Arctic vegetation: consistent evidence from an experimental manipulation and a natural event. Journal of Ecology. http:// dx.doi.org/10.1111/j.1365-2745.2009.01554.x.

Brosset, C., Andreasson, K., Ferm, M., 1975. On the nature and possible origin of acid particles observed at the Swedish west coast. Atmospheric Environment 8, 631

Chaiyo, U., Garivait, S., Wilairat, D., 2011. Trace elements and carbon contents in particulate emissions from tropical deciduous forest fires in Chiangmai, Thailand. In: Proceedings from the 2nd International Conference on Environmenta Science and Technology IPCBEE, vol. 6. IACSIT Press, Singapore.

Corbett, J.J., Lack, D.A., Winebrake, J.J., Harder, S., Silberman, J.A., Gold, M., 2010 Arctic shipping emissions inventories and future scenarios. Atmospheric Chemistry and Physics 10, 9689-9704. http://dx.doi.org/10.5194/acp-10-96892010.

Cornelissen, J.H.C., Callaghan, T.V., Alatalo, J.M., Michelsen, A., Graglia, E., Hartley, A.E., Hik, D.S., Hobbie, S.E., Press, M.C., Robinson, C.H., Henry, G.H.R. Shaver, G.R., Phoenix, G.K., Jones, D.G., Jonasson, S., Chapin, F.S., Molau, U., Neill, C., Lee, J.A., Melillo, J.M., Sveinbjornsson, B., Aerts, R., 2001. Global change and arctic ecosystems: is lichen decline a function of increases in vascular plant biomass? Journal of Ecology 89, 984-994.

Dise, N., Ashmore, M., Belyazid, S., Bleeker, A., Bobbink, R., de Vries, W. Erisman, J.W., Spranger, T., Stevens, C.J., van der Berg, L., 2001. Nitrogen as a threat to European terrestrial biodiversity. In: Sutton, Mark A., Howard, Clare 
M., Erisman, J.W., Billen, G., Bleeker, A. (Eds.), The European Nitrogen Assessment: Sources, Effects and Policy Perspectives, ISBN 978-1-107-00612-6, pp. 463-494.

EMEP, 1996. EMEP Manual for Sampling and Chemical Analysis. EMEP/CCC-Report 1995. Last Revision in 2001. Norwegian Institute for Air Research, Kjeller. Available from: www.nilu.no/projects/ccc/manual/index.html.

Erisman, J.-W., Draaijers, G., Duyzer, J., Hofschreuder, P., van Leeuwen, N., Römer, F., Ruijgrok, W., Wyers, P., Gallagher, M., 1997. Particle deposition to forests summary of results and application. Atmospheric Environment 31, 321-332.

Ferm, M., 1993. Throughfall measurements of nitrogen and sulphur compounds. International Journal Analytical Chemistry 50, 29-43.

Ferm, M., 1998. Atmospheric ammonia and ammonium transport in Europe and critical loads - a review. Nutrient Cycling in Agroecosystems 51, 5-17.

Ferm, M., Hellsten, S., 2012. Trends in atmospheric ammonia and particulate ammonium concentrations in Sweden and its causes. Atmospheric Environment 61, 30-39.

Flannigan, M., Stocks, B., Turetsky, M., Wotton, M., 2009. Impacts of climate change on fire activity and fire management in the circumboreal forest. Global Change Biology 15, 549-560.

Galloway, J.N., Dentener, F.J., Capone, D.G., Boyer, E.W., Howarth, R.W. Seitzinger, S.P., Asner, G.P., Cleveland, C.C., 2004. Nitrogen cycles: past, present, and future. Biogeochemistry 70, 153-226.

Goldammer, J., 2010. International Forest Fires News. No. 40 July-December 2010 UNECE ECE/TIM/IFFN/2010/2. http://www.fire.uni-freiburg.de/iffn/iffn.htm.

Gordon, C., Wynn, J.M., Woodin, S.J., 2001. Impacts of increased nitrogen supply on high Arctic heath: the importance of bryophytes and phosphorus availability. New Phytologist 149, 461-471.

Hecobian, A., Liu, Z., Hennigan, C.J., Huey, L.G., Jimenez, J.L., Cubison, M.J., Vay, S. Diskin, G.S., Sachse, G.W., Wisthaler, A., Mikoviny, T., Weinheimer, A.J., Liao, J., Knapp, D.J., Wennberg, P.O., Kürten, A., Crounse, J.D., Clair, J. St, Wang, Y., Weber, R.J., 2011. Comparison of chemical characteristics of 495 biomass burning plumes intercepted by the NASA DC-8 aircraft during the ARCTAS/ CARB-2008 field campaign. Atmospheric Chemistry and Physics 11, 1332513337. http://dx.doi.org/10.5194/acp-11-13325-2011.

Hertel, O., Reis, S., Ambelas Skjøth, C., Bleeker, A., Harrison, R., Cape, J.N., Fowler, D., Skiba, U., Simpson, D., Jickells, T., Baker, A., Kulmala, M., Gyldenkærne, S., Sørensen, L.L., Erisman, J.-W., 2011. Nitrogen processes in the atmosphere. In: Sutton, Mark A., Howard, Clare M., Willem Erisman, Jan, Billen, Gilles, Bleeker, Albert (Eds.), The European Nitrogen Assessment: Sources, Effects and Policy Perspectives, ISBN 978-1-107-00612-6, pp. 177-207.

Hole, LR., Christensen, J., Ruoho-Airola, T., Tørseth, K., Ginzburg, v.A., Glowacky, P., 2009. Past and future trends in concentrations of sulphur and nitrogen compounds in the Arctic. Atmospheric Environment 43, 928-939.

Hole, L.R., Enghardt, M., 2008. Climate change impact on atmospheric nitrogen deposition in northwestern Europe - a model study. Ambio 37, 9-17.

Hyvärinen, A.-P., Kolmonen, P., Kerminen, V.-M., Virkkula, A., Leskinen, A. Komppula, M., Hatakka, J., Burkhart, J., Stohl, A., Aalto, P., Kulmala, M. Lehtinen, K.E.J., Viisanen, Y., Lihavainen, H., 2011. Aerosol black carbon at five background measurement sites over Finland, a gateway to the Arctic. Atmospheric Environment 45, 4042-4050.

Irwin, J.G., Williams, M.L., 1988. Acid rain - chemistry and transport. Environmenta Pollution 50, 29-59.

ISO 9835, 1993. Ambient Air - Determination of a Black Smoke Index.

Karlsson, V., Pyy, K., Saari, H., 2007. Measurement uncertainty of sulphur and nitrogen containing inorganic compounds by 1-stage and 2-stage filter-pack methods. Water, Air and Soil Pollution 182, 395-405.

Karlsen, S.R., Høgda, K.A., Wielgolaski, F.E., Tolvanen, A., Tommervik, H., Poikolainen, J., Kubin, E., 2009. Growing-season trends in Fennoscandia 19822006, determined from satellite and phenology data. Climate Research 39, 275-286.

Krupa, S.V., 2003. Effects of atmospheric ammonia $\left(\mathrm{NH}_{3}\right)$ on terrestrial vegetation: a review. Environmental Pollution 124, 179-221.

Kühnel, R., Roberts, T.J., Björkman, M.P., Isaksson, E., Aas, W., Holmen, K., Ström, J., 2011. 20-year climatology of $\mathrm{NO}_{3}^{-}$and $\mathrm{NH}_{4}^{+}$wet deposition at Ny-Alesund,
Svalbard. Advances in Meteorology 2011, 10. http://dx.doi.org/10.1155/2011/ 406508. Article ID 406508.

Lamarque, J.-F., Bond, T.C., Eyring, V., Granier, C., Heil, A., Klimont, Z., Lee, D., Liousse, C., 2010. Historical (1850-2000) gridded anthropogenic and biomass burning emissions of reactive gases and aerosols: methodology and application. Atmospheric Chemistry and Physics 10, 7017-7039. http://dx.doi.org/10.5194/ acp-10-7017-2010.

Manninen, S., Huttunen, S., Tømmervik, H., Hole, L., Solberg, S., 2009. Northern plants and ozone. Ambio 38, 406-412.

Parker, 1983. Throughfall and stemflow in the forest nutrient cycle. Advances in Ecological Research 13, 58-133.

Pihl Karlsson, G., Akselsson, C., Hellsten, S., Karlsson, P.E., 2011. Reduced European emissions of $\mathrm{S}$ and $\mathrm{N}$ - effects on air concentrations, deposition and soil water chemistry in Swedish forests. Environmental Pollution 159, 3571-3582.

Phoenix, G.K., Emmett, B.A., Britton, A.J., Caporne, S.J.M., Dise, N.B., Helliwell, R., Jones, L., Leake, J.R., Leith, I.A., Sheppard, L.J., Sowerby, A., Pilkington, M.G., Rowe, E.C., Ashmore, M.R., Power, S.A., 2012. Impacts of atmospheric nitrogen deposition: responses of multiple plant and soil parameters across contrasting ecosystems in long-term field experiments. Global Change Biology 18,1197-1215.

Ruoho-Airola, T., Salmi, T., 2001. Episodicity of sulphate deposition in Finland. Water, Air, and Soil Pollution 130, 529-534.

Ruoho-Airola, T., Eilola, K., Savchuk, O.P., Parviainen, M., Tarvainen, V., 2012. Atmospheric nutrient input to the Baltic Sea for 1850-2006: a reconstruction from modeling results and historical data. AMBIO 41, 549-557. http://dx.doi.org/ 10.1007/s13280-012-0319-9.

Saarikoski, S., Sillanpää, M., Sovief, M., Timonen, H., Saarnio, K., Teinilä, K., Karppinen, A., Kukkonen, J., Hillamo, R., 2008. Chemical composition of aerosols during a major biomass burning episode over northern Europe in spring 2006: experimental and modelling assessments. Atmospheric Environment 41, 35773589.

Simmonds, P.G., Manning, A.J., Derwent, R.G., Ciais, P., Ramonet, M., Kazan, V., Ryall, D., 2005. A burning question. Can recent growth rate anomalies in the greenhouse gases be attributed to large-scale biomass burning events? Atmospheric Environment 39, 2513-2517.

Stevens, C., Dupre, C., Gaudnik, C., Dorland, E.N., Gowing, D., Bleeker, A., Alard, D., Bobbink, R., Fowler, D., Vandvik, V., Corcket, E., Mountford, J.O., Aarrestad, P.A., Muller, S., Diekmann, M., 2011. Changes in species composition of European acid grasslands observed along a gradient of nitrogen deposition. Journal of Vegetation Science 22, 207-215.

Stohl, A., Berg, T., Burkhart, J.F., Fjæraa, A.M., Forster, C., Herber, A., Hov, Ø., Lunder, C. 2007. Arctic smoke - record high air pollution levels in the European Arctic due to agricultural fires in Eastern Europe. Atmospheric Chemistry and Physics 7, 511-534.

Tørseth, K., Aas, W., Breivik, K., Fjæraa, A.M., Fiebig, M., Hjellbrekke, A.G., Lund Myhre, C., Solberg, S., Yttri, K.E., 2012. Introduction to the European Monitoring and Evaluation Programme (EMEP) and observed atmospheric composition change during 1972-2009. Atmospheric Chemistry and Physics 12, 5447-5481.

van der Werf, G.R., Randerson, J.T., Giglio, L., Collatz, G., Kasibhatla, P.S., Arellano Jr., A.F., 2006. Interannual variability of global biomass burning emissions from 1997 to 2004. Atmospheric Chemistry and Physics Discussion 6, 3175-3226.

Vestreng, V., Ntziachristos, L., Semb, A., Reis, S., Isaksen, I.S.A., Tarrasón, L., 2009. Evolution of $\mathrm{NO}_{x}$ emissions in Europe with focus on road transport control measures. Atmospheric Chemistry and Physics 9, 1503-1520.

Whitham, C., Manning, A., 2007. Impacts of Russian biomass burning on UK air quality. Atmospheric Environment 41, 8075-8090.

Yurganov, L.N., Duchatelet, P., Dzhola, A.V., Edwards, D.P., Hase, P., Kramer, I. Mahieu, E., Mellqvist, J., Notholt, J., Novelli, P.C., Rockmann, A., Scheel, H.E., Schneider, M., Schulz, A., Strandberg, A., Sussmann, R., Tanimoto, H., Velazco, V., Drummond, J.R., Gille, J.C., 2004. Increased Northern Hemisphere carbon monoxide burden in the troposphere in 2002 and 2003 detected from the ground and from space. Atmospheric Chemistry and Physics Discussion 4, 4999-5017. 